\title{
TOWARDS THE RIGHT MODEL OF SMART CITY GOVERNANCE IN INDIA
}

\author{
SARBESWAR PRAHARAJ, JUNG HOON HAN \& SCOTT HAWKEN \\ Faculty of Built Environment, University of New South Wales, Sydney, Australia.
}

\begin{abstract}
There is broad agreement among the scientific community that local government's play a vital role in fostering smart cities which focusses on improving quality of life by integrating technology with the built environment. But, urban governance in rapidly urbanising countries of global south is often poorly organised to deal with complex urban challenges, severely hindering their aspirations to become smart cities. Although smart city dossiers are abundant in literature, their governance framework and structural variations in such development across regions is lacking. Furthermore, efforts to import governance models from developed world cities are facing lack of unique context sensitivities, which stand against their transformation as smart cities. This paper contributes to the debate on urban governance of smart cities by providing their distinct theoretical conceptualisations and linking them with case studies. It analyses the urban governance dynamics in Indian cities which has started implementing a massive 100 smart cities development programme. From the past experiences of Indian cities in reforming urban administration to its new model of special purpose vehicle led project execution; this research critically assesses the ability of Indian cities to transform their traditional bureaucratic governments into a more accountable collaborative governance. The outcomes from this study highlight the need for aspiring smart cities in emerging economies to address deep-seated structural issues of municipal government's and engage in the process of governance transformation rather than adopting temporary solutions.
\end{abstract}

Keywords: smart cities mission in India, smart city, smart governance, urban governance.

\section{INTRODUCTION}

India has experienced a dramatic surge of urbanisation over the last several decades. The urban population share of the country has risen from $17.96 \%$ in the year 1961 to $31.2 \%$ in the year 2011. By 2040, the nation is expected to house half of its population in urban areas. Presently India's urban population totals around 410 million and is estimated to reach a staggering 814 million by 2050 [1]. The urban sector has also emerged as the key to stimulating India's economic growth and future prosperity contributing more than 60 percent of the national economic output, and nearly 80 percent of the total tax revenue. By $2021,75 \%$ of the country's GDP will be contributed by the urban sector and by then over $70 \%$ of new jobs shall be concentrated in India's cities. However, the state of Indian cities, concerning development and maintenance of urban infrastructure and public service delivery remains highly unsatisfactory [2], challenging urban India's potential to drive sustained economic development. Against this background, the Strategic Plan of Ministry of Urban Development, Government of India for 2011-2016 [3], commented that for enhancing the competitiveness of cities while offering basic services to citizens, urgent steps are required to harness the opportunity that the scale of urbanisation presents. To address India's urbanisation challenges, the erstwhile Planning Commission of India in its twelfth plan period envisioned a first of its kind creation of smart urban centres in India. In the plan [4], smart cities were proposed as the engines of growth, competing for investment for infrastructure upgrading. Digital technologies were conceived as a way to address the urban infrastructure deficit in Indian cities, and to also promote sustainable development. 
The Government of India under the leadership of Prime Minister Narendra Modi has faced the dramatic urbanisation challenge by rolling out an ambitious mission to develop 100 smart cities across the rapidly urbanising country. The 'Smart Cities Mission' (smartcities.gov.in), initiated in the year 2015, aims to drive economic growth and improve the quality of life for people in selected cities by enabling local development and harnessing technology as a means to create smart solutions for citizens. The mission has proposed the outlay of US\$7.5 billion for investment across 100 cities over a period of five years. A competitive city challenge invited the selected cities to submit their smart city proposals to receive funding under the mission. Based on their proposals, the top 20 scoring cities started receiving funding in Round 1, and consequently, Round 2 and Round 3 of the challenge approved proposals from 40 cities. Round 4 of the selection process is currently underway where another 40 plus cities are competing. Each of these cities is set to implement at least one infrastructure solution (such as improved water supply system, transport infrastructure development etc.) that is of benefit to their entire city population. These cities are also beginning to undertake area-based development of a selected urban quarter (not more than 200 hectares) to develop as smart lighthouse districts. These large-scale spatial development and infrastructure upgrading proposals aspire to use cutting-edge digital and information and communication technology (ICT) to transform India's urban landscape.

As the government's flagship mission moves from conceptualisation towards the implementation phase, questions have arisen regarding the mission. Debates over execution have gained in intensity amidst calls for closer review of the factors involved [5] and the need to incorporate learning from previous such programmes [6]. A key uncertainty that has emerged in the process is whether urban local bodies (ULB's) in India have the organisational capability to meet the challenges posed by these new type developments. Ironically, these questions emerged from the Government of India's urban policy assessment that points to political economy factors and inadequate management capacity as key challenges impacting effective urban reform in India [3]. Various well-regarded global enterprises such as World Economic Forum [1] and Brooking Institution [7] in their assessment on smart city development in India highlighted that the concept of a planned urban administration is yet to be addressed in India's cities. They observed that the current nature of government silos will pose a major challenge in execution of mega future developments. A significant feature of the Smart Cities Mission (SCM) is the central role entrusted by the Government of India on special purpose vehicles (SPV's) for the implementation of smart city projects. These are companies formed by a joint partnership between the state and municipal local bodies to expedite the process of development. But, how the formation of SPV's will impact the process of empowerment of municipal corporations and the way in which this newly created entity will coordinate with conventional forms of local government's and parastatals (infrastructure delivery agencies operating at city level but controlled by the state government) is yet to be seen.

This paper in an attempt to answer some of these questions adopts a three-tier analysis framework. Firstly, a literature review presents an understanding of the various types of governance in smart cities. Secondly, the existing state of urban governance and outcomes from past initiatives of governance reforms in Indian cities are analysed. Then in the purview of Smart Cities Mission, the special purpose vehicle model is uncovered, accompanied by an assessment of a series of emerging conflicts with the existing urban organisational setup. The aim of the paper is not to endorse a specific governance model for Indian cities but examine their ability to transform governance arrangements to deliver smart city projects. 


\section{SMART GOVERNANCE TYPOLOGIES: A THEORETICAL VIEW}

Traditionally the term 'govern' is defined as "to rule or exercise authority and to manage and administer the affairs of a state or territory" [8]. 'Government' was the most commonly used nomenclature in the mid-20th century that refers to "the formal public institutional structure and location of authoritative decision making, consisting of the political and bureaucratic layers of state apparatus" [9]. This model of top-down, command and control government has failed to address the emerging socio-economic change and complexity of a pluralistic state, and a greater need for coordination, negotiation and building consensus among a diverse range of stakeholders was realised [10]. The concept of 'governance' emerged in this context that refers to "the system or style of governing where the boundary between public and private, formal and informal, state and civil society sectors become permeable" [8]. The essence of governance lies in the desire to achieve mutual solutions through cooperation between the government and the forces that operate outside them [9]. Of late, urban governance has transformed into a mature academic field with the shift from welfare-state model towards economic development model, which demands the government's to be more innovative and entrepreneurial in an increasingly competitive world [11]. Moreover, this discipline is being increasingly associated with digital technology to develop approaches that can make cities smarter [12]. We are seeing a trend where researcher from the field of information technology is starting to become interested in the governance of the city, and on the other hand, professionals in urban governance and built environment are beginning to adapt with smart technology. Fruitful connections among these academic fields require repositioning of concepts such as technology, governance and smart cities in theoretical perspectives.

The concept of Smart Cities relying on the foundations of urban innovation, creative policies and information and communication technology has attracted considerable attention from the political class, city and the federal governments across the globe as a response to solve tangled and wicked problems in the context of rapid urbanisation. But, a critical review of literature indicates that smart cities commentary tend to highlight the technological aspects of a smart city, while it's distinct political setting, governing and policy issues have not received much attention [12]. Hollands [13] believes that the cities which have begun calling themselves smart cities, often lack a comprehensive understanding about the nature of governance reorganisation required in the purview of emerging digital revolution. Further success and development of smart cities demand 'smart governance' frameworks that are capable of both integrating all of the political, social, and economic aspects and allow seamless digital connectivity and services to produce the best returns in public value and benefits. The lack of governance instruments for smart cities could represent the most serious barrier to their successful implementation [14]. Amidst this call for new type urban governance, different cities across the globe have adopted different strategic perspectives on the role of government in context to smart cities development. Their approaches on the need for transformation of government also significantly differ as a way to make cities smarter. Some conservative assessments indicate traditional institutional arrangements can deliver smart cities, while more thorough investigations suggest that government itself needs to be transformed to create a smart city [15].

To capture the typology of governance frameworks and the degree of institutional transformation in smart cities across the globe, this research has undertaken an extensive full-text analysis of 21 research papers focussing on smart cities governance, published in established journals, book chapters and conference proceedings beginning from the year 1999 till 2016. 
We have also analysed the websites of known global smart cities to identify the nature and style of governance in those cities. A parallel between literature analysis and case study assessment were drawn to provide an explicit understanding of the role of government in shaping smart cities. As an outcome from the investigation, we recognised four distinct conceptualisations of smart city governance: (I) traditional government as the promoter of smart city, (II) data and sensor linked informed governance, (III) electronic governance for smart administration and (IV) collaborative smart governance.

Smart cities are often interested in adopting the 'smart' label [13] to create the desired image for place marketing purposes [16] as opposed to actual transformation on the ground. Cities with such policies bank on traditional governance as the promoter of a smart city [17]. Global technology and marketing vendors support cities in such urban image building by creating dazzling websites with visualisations and videos for distribution on the internet and social media to attract global capital and limelight. In this conceptualisation, as shown in Fig. 1, smart governance translates into the government of a smart city that makes the right policy choices and implements them effectively [15]. Batty et al. rightly indicates that whenever a city is promoting itself as smart, the smart governance attribute is associated by default as an entity for urban management and negotiator [18]. Gujarat International Finance Tech-City popularly known as GIFT smart city (giftgujarat.in) is a classic example of smart city marketing. Located in the western Indian state of Gujarat, GIFT smart city has been conceived as a green-field development without the presence of any local government. The city is entirely master planned by consultant and promoted by the state government as a global financial hub. It is one of the most publicised projects in India with a glamorous website and several promotional videos doing rounds in the social media for several years without any significant physical development on the ground. This type of self-designated smart city indicates a subtle shift in urban governance from managerial to entrepreneurial forms borrowed as part of ongoing policy tourism [19] from western cities to the global south. The underlying emphasis of such ventures is less on governing and more on attracting business and investment, as can also be seen in the smart city webpage of Edmonton, Canada, where the features of the smart city are primarily linked to business environment and business-led economy [13].

Data and sensor linked informed governance is the second type of conceptualisation of smart governance, focusing on the application of technology for capturing real-time data to make sense of cities and solve real-life challenges. This nature of governance emphasises more on smart decision-making processes [20] and informed execution of those decisions. The level of governance transformation in this model is insubstantial as it relies more on the power of technology and big data, rather than the restructuring of organisations. This governance model is synonymous with United Nations framework on good governance [21], which highlights that the process of decision making in a governance setting is the key for sustainable smart cities development. Sensor and network technology play a vital role in this type of conceptualisation of smart governance where various layers of data regarding human movement and behaviour, environmental performance and flow of services and infrastructure are monitored continuously. These information's helps cities to become innovative while making decisions and allow government's to open up data for use by public and businesses. Strong open data policies and substantial investments in IoT solutions are critical to the success of modern cities that are looking to employ structures for data-informed decision making and implementation of smart city initiatives. The bustling port city Santander situated on the north coast of Spain is perhaps the ideal example of sensored city with a dense concentration of installed sensors dotted around the city's streets. To develop a robust urban decision-making 
and monitoring system, the smart city Santander (www.smartsantander.eu) is using IoT to unite all the information's coming from sensors. The city through its sensor networks collects real-time data on emissions, energy use, noise levels, temperature and a whole range of civic services. Cities such as Bristol and Manchester in the UK are a stage ahead in this revolution of data centred urban development. 'Bristol Open Programmable City" project (www.bristolisopen.com) is anonymising all the data generated from sensors and making them public through open data portal (opendata.bristol.gov.uk). This style of governance, beyond the collection of data for smart decision making, strives to incorporate challenges of digital inclusion and data privacy. Such model of capturing real-time data and streaming them through digital platforms are fast becoming a favourite mode of smart urban governance.

The next level of conceptualisation of smart governance suggests that cities must use electronic governance tools, supported by cutting-edge information technologies to integrate internal government system [22] to become smart. This form of governance, as shown in Fig. 1, is also termed as 'smart administration' [23]. The key goal of a smart administration is to break silos within the government departments by interconnecting institutions, policies, information's and physical infrastructure to better serve citizens and local communities. Batty et al. argued that smart governance require a high level of intelligence from government's in dealing with coordination among different components that comprise the smart city [18]. It is a system bound by operating technical standards that helps to concatenate traditional functions of government with emerging digital technologies for enhanced efficiency. This nature of smart governance is at a higher level of transformation than earlier conceptualisations as it requires a complete restructuring of the government's internal institutional arrangements [15]. It also addresses the challenge of integrating different policies and plans from the different sector for effective urban innovation [12]. The smart administration model of Singapore is an ideal prototype of this conceptualisation. As part of its Smart Nation Programme (www.smartnation.sg), the Infocomm Development Authority (IDA) of Singapore has developed IoT foundational standards for information and service interoperability across

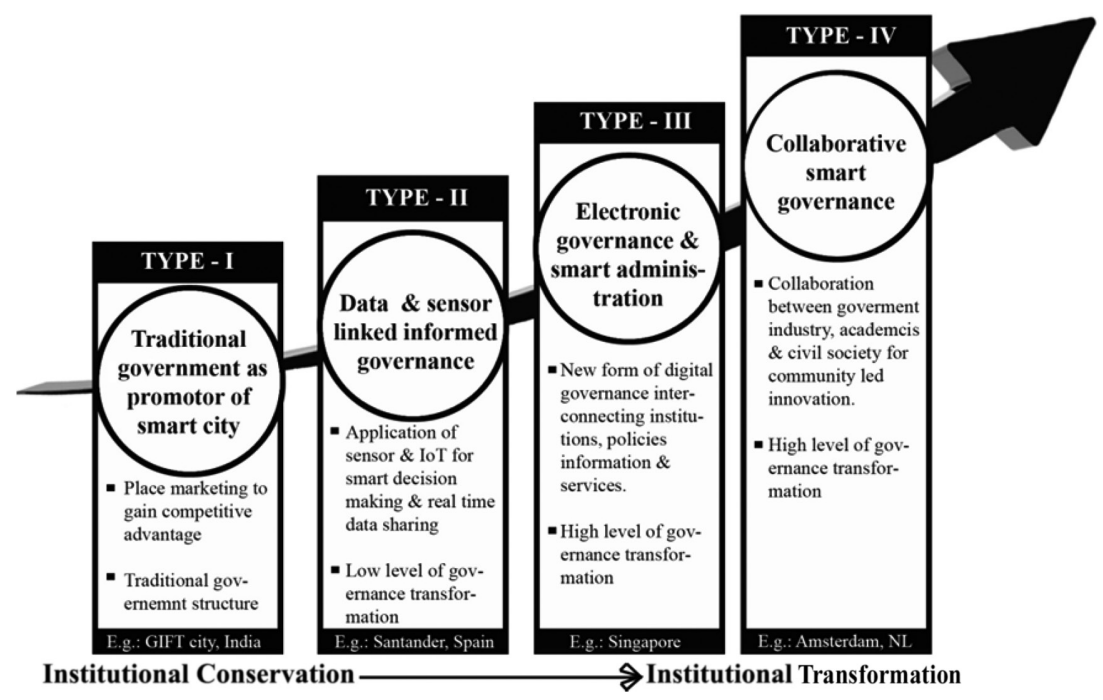

Figure 1: Various conceptualisations of smart city governance. 
infrastructure sectors. It operates on TR38 technical reference standard for sensor network in public areas and the TR40 technical reference for sensor network for homes - to ensure seamless information-sharing and improve sensing capabilities across services and devices. This interconnectedness among infrastructure layers is governed singularly by Infocomm Development Authority (IDA) directly operating under Smart Nations Programme office of the Prime Minister. Integrated governance capability provides Singapore with the ability to monitor service use in each home within the territory of the state with much of the data feeding into an online 3D City platform-'Virtual Singapore'. This platform is set to provide the government with an unprecedented power to look into how the country is functioning in realtime, allowing them to predict impacts of events and manage them remotely. It is important to note, that smart administration as a conceptualisation of smart governance in Singapore has mostly benefited from its manageable urban scale, and the absence of overlapping state, local and federal bureaucracies.

Beyond right policies and integrated administration, megacities require a robust managerial framework to build collaboration between government and other stakeholders for fostering urban innovation [24]. The fourth conceptualisation of smart city governance stresses on 'collaboration' as a key dimension. In this model, the degree of governance transformation is very high, as it does not only require integration of internal government structure but also demand partnership building with external organisations [15]. Nam and Pardo [12] believe that smart governance primarily flows through collaboration across government, industry, university, NGO's and most importantly people; a process employed to make government operations and service delivery virtuously citizen-centric. This model of urban governance rather than merely depending on technological platforms, harnesses the collective intelligence and creativity of local citizens. This form of collaborative smart governance also aims to create 'innovation hubs' [26] through productive interactions between networks of urban actors, knowledge centres and resource organisations; maximising the social, economic and ecological performance of cities. An ideal example of collaborative urban governance is the Amsterdam Smart City (amsterdamsmartcity.com) which is a unique partnership between the city government, businesses, research institutions, start-ups and innovators, investors and common citizens. With an extensive partnership of over 2207 individuals and organisations, Amsterdam Smart City has build numerous projects encompassing six themes. These include- (a) infrastructure and technology, (b) energy, water and waste, (c) mobility, (d) circular city, (e) governance and education and (f) citizen and living. The city presents itself as an 'urban living lab' that invites entrepreneurs to use openly available data from public and private sources, design apps and test pilot innovative solutions for improving services and business. In Amsterdam, a big part of shaping the smart city is engaging citizens and local communities through "Smart Citizen" project, which attract people to participate as agents of crowdsourced data. Residents themselves in Amsterdam act as sensors demonstrating their awareness of sustainability challenges and directly engaging with their city supporting its elevation as a smart city. This model of smart governance is strikingly different from earlier conceptualisations that stresses more on the role of government, than harnessing the collective creativity of its stakeholders and citizens.

The diverse conceptualisations of smart governance introduced in this section provide choices for cities to adopt a framework that suits their political context but have raised many questions unresolved. The principal problem is defining the role of government's in smart cities. Should they embrace a leading role in developing smart city visions and its execution? Is it better for governments to play the role of enabler and coordinate smart city projects 
through collaboration and partnerships? Or they need to adopt urban place marketing strategies to remain competitive? With these questions in mind, let us examine the existing urban governance framework in India cities and their approach towards smart governance in the purview of India's 100 Smart Cities Mission.

\section{URBAN GOVERNANCE IN INDIA}

Municipal government in India have a history of over 300 years. Madras (presently known as Chennai) was the first municipal corporation in the country set up as early as 1687 . Calcutta and Bombay, the other two primate cities followed Chennai to have their city corporation in the year 1726 [1]. Although these municipal governments were in existence, the Indian Constitution did not recognise them as autonomous entities. They remained entirely under the control of state legislatures for a prolonged period even after India's independence in 1947. A notable change in the trajectory of India's urban governance came in 1992 the passing of the 74th Constitutional Amendment Act (CAA). The 74th CAA had provision for the empowerment of urban local bodies (ULB) inserted for the very first time in the Constitution of India. Twelfth Schedule of the 74th CAA directed the states to devolve power to local bodies related to functions such as urban planning, regulation of land-use, planning for economic and social development, construction of roads and bridges, water supply and public health, sanitation etc. Although this Act had all the necessary ingredients to strengthen India's urban governance, there were no incentives or clear framework for either states or cities to execute the provisions. In the year 2005, Jawaharlal Nehru National Urban Renewal Mission (JnNURM), a massive initiative by the Government of India was launched to fast-track implementation of urban reforms across 67 selected cities in the true spirit of the 74th CAA. Progress in the execution of reforms by the state and ULB's were linked with the disbursement of funding for infrastructure development [27]. Although better urban infrastructure and improved service delivery were conceived as an outcome from JnNURM, the main thrust was on creating a process for cities to ensure improvement in urban governance. It also aimed to make the ULB's become financially sound and develop the capacity to undertake largescale development projects [28].

Nearly 20 years after the passing of 74th CAA and seven years of JnNURM in action, the Government of India's High Powered Expert Committee (HPEC) on urban infrastructure and services [29] revealed that governance and accountability had remained the weakest and most crucial link in India's urban transformation. The report adds that JnNURM has, in fact, more exposed the lack of capacity at the local government level to tackle infrastructure projects. This observation comes as a result of the dismal performance of cities to implement urban reforms under JnNURM and the emergence of an adamant state that is reluctant to devolve power and financial control to ULB's [30]. Urban development is still very much a state subject in India; town planning and critical physical infrastructure delivery are performed by parastatal agencies [28]. Although the 74th CAA, as well as JnNURM, mandated the transfer of urban planning functions, as of date 12 states (see Fig. 2) across India are yet to transfer functions of the 12th schedule to cities [27]. Whereas some states did not devolve power due to the anxiety of losing administrative control to cities, many of the urban local bodies lacked adequate capacity to take over functions such as urban planning, roads and bridges, water supply, sanitation etc. [30]. The dominant role of the state level organisations the implementation of the JnNURM projects has significantly lowered the moral of democratically elected municipal government's. It has also raised the level of unaccountability in 


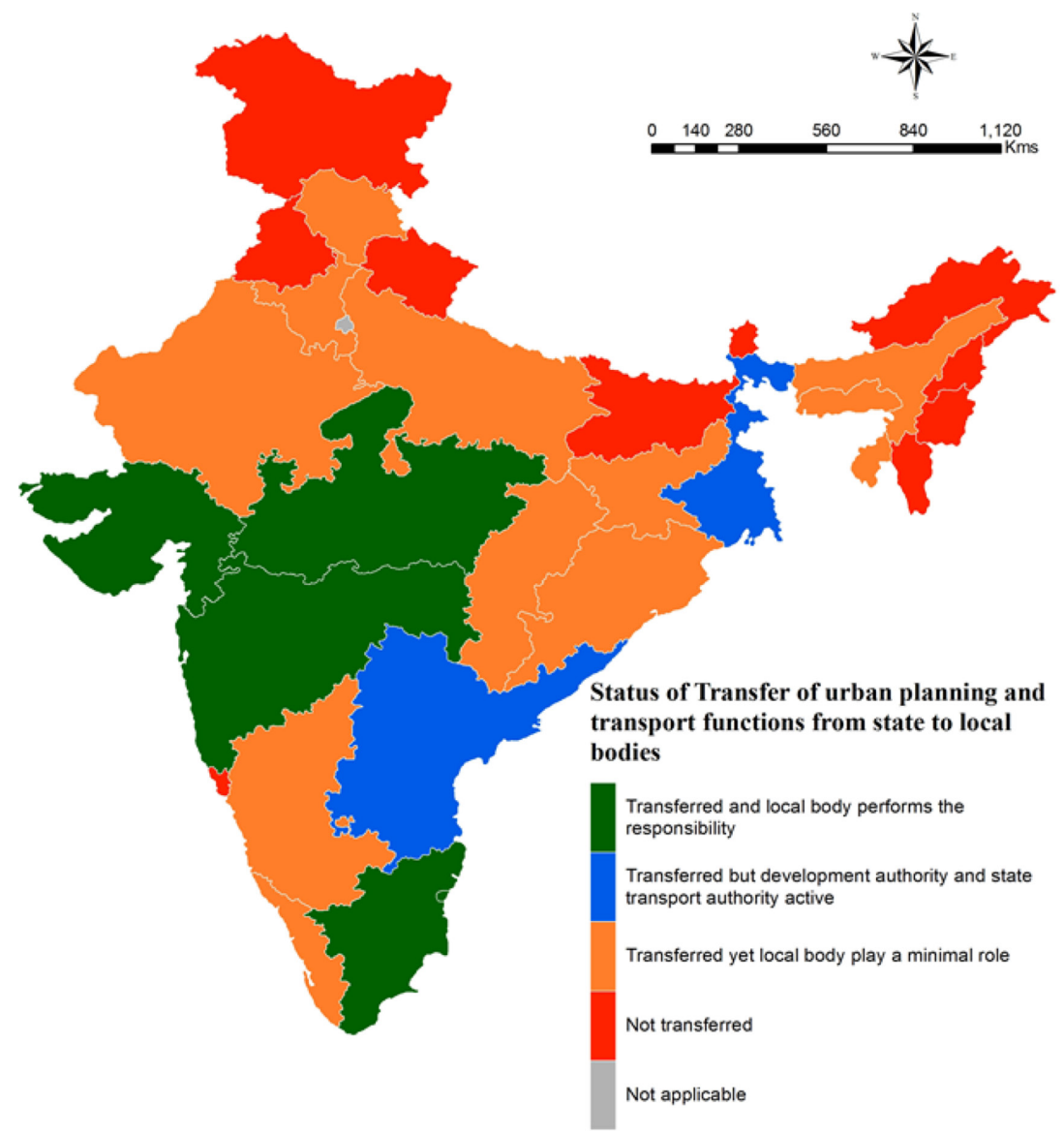

Figure 2: Status of transfer of urban planning and transport functions as per 74th CAA.

planning and service delivery as the auditing agencies does not have jurisdictions over the non-elected parastatal agencies.

E-governance implementation was one of the most significant city level reforms introduced by JnNURM. This reform aimed at linking municipal departments electronically, with the potential to increase service delivery efficiency and accountability of civil administration. Eight modules were targeted for implementation by urban local bodies under this reform, including the online issue of birth and death certificate, an online payment system for property tax, water charge, and other utility bills, online building approval etc. Only 38 cities among 67 JnNURM mission cities have been able to implement all these eight modules [27]. Because E-governance is an essential enabler for smart cities governance as observed in the discussions in the previous section, we were keen to know the dynamics behind this variation in the execution of the E-governance reforms in Indian cities. We mapped cities under JnNURM according to their population size and coloured them differently as per the status of implementation of E-governance reforms. We observed, as shown in Fig. 3, all the megacities (more than 20 million populations) were able to implement the E-governance reform; whereas all the small towns (less than 0.5 million population) have failed to execute the reform. This 


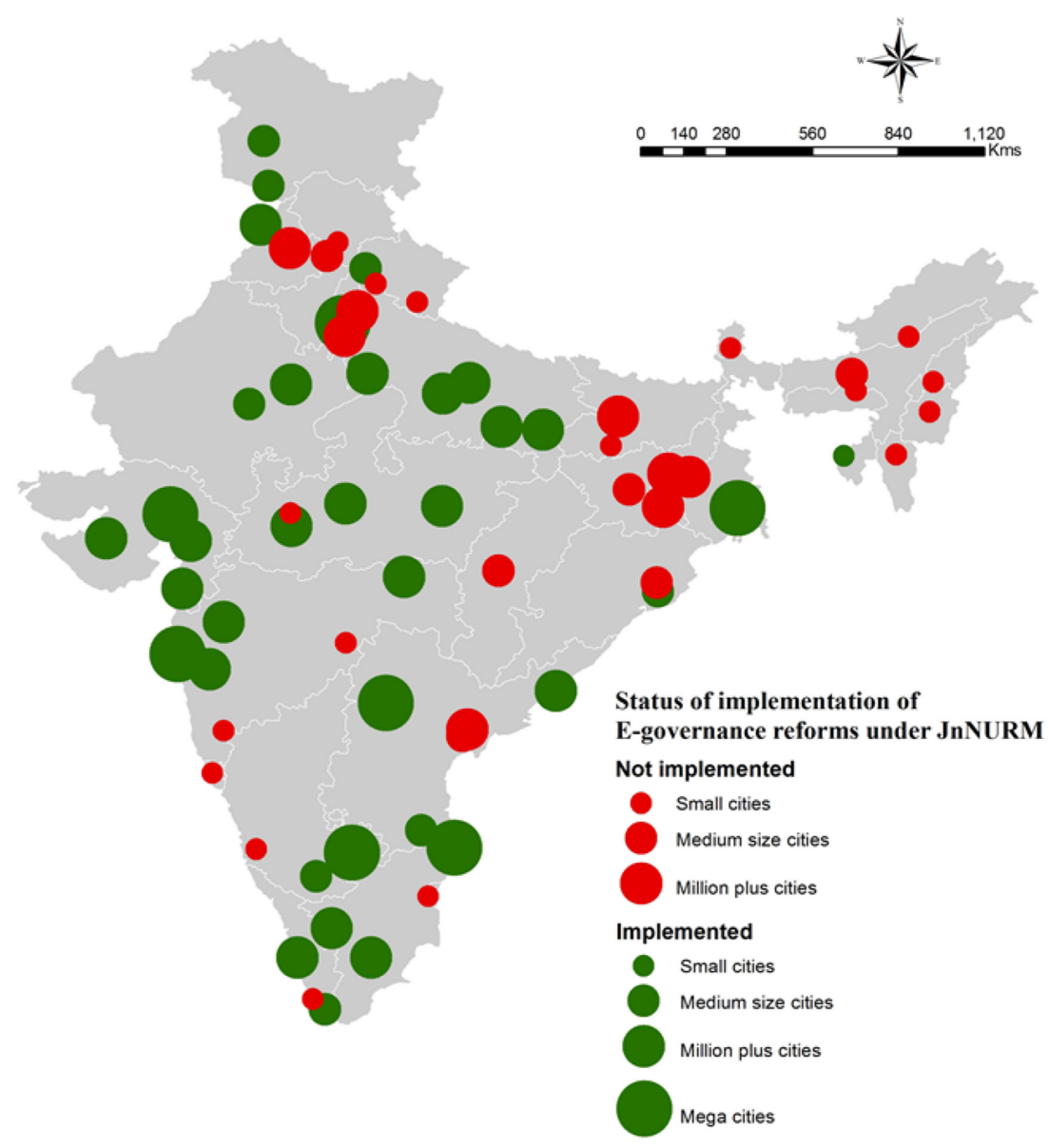

Figure 3: Status of implementation of E-governance reforms under JnNURM.

trend has exposed severe lack of capacity and resources with smaller urban local bodies in India that has been unable to deal with emerging governance needs.

Moving beyond measuring the performance of Indian cities in implementing governance reforms in the past, we have looked into the present state of urban local bodies with an emphasis on digital governance and service delivery across 100 cities selected under Smart Cities Mission. A dedicated municipal website is the first step towards electronic governance [31]. The type and amount of information across city government websites may vary, but generally, it contains information regarding the city profile, organisational structure, service delivery benchmarks, annual budgets, tenders, contact details of the municipal staff etc. Leading city government websites also provides open data and interface for approval of buildings, water connection, electricity, and live traffic updates etc. [32]. An analysis of the availability of municipal websites done as part of this study shows that one-tenth of cities under the 100 Smart Cities Mission does not have a dedicated website. Good municipal governance is directly linked with the level of transparency in functioning and sharing of information by the governments to the citizen [33]. Municipal budget is an important document that has high interest among citizens as it is the public money that the government's 
supposed to utilise efficiently. We analysed the available websites of 90 cities among 100 nominated smart cities to find if there was municipal budget uploaded to it for open viewing and downloading. We found, as shown in Fig. 4, 12 out of 90 cities do not have official budget shared through its websites. About 21 out of 90 websites does not allow downloading of municipal budget, and they are available simply as an abstract budget overview. The findings suggest that Indian cities although keen to attach a "smart" label on themselves, lack elementary features of digital governance and are uninterested in sharing critical information with citizens.

Active monitoring, benchmarking and publication of service delivery performance, as well as the robustness of public grievance redressal mechanism, are essential pillars of sound urban governance. As part of this study, we have collected and analysed information on the status of publication of service level benchmarks and availability of single window civic service centres in ULB's across 100 designated smart cities in India. Service level benchmarking is seen as a mechanism that helps cities to track performance over time and compare their performance with that of their peers [34]. It allows policymakers to identify areas for optimisation, set realistic future performance targets and disclose the performance data to citizens and stakeholders to address accountability issues. The Ministry of Urban Development, Government of India as well as the 13th Finance Commission (2010-2015) have urged cities to collect data on service level and report in a reliable format on a systematic and

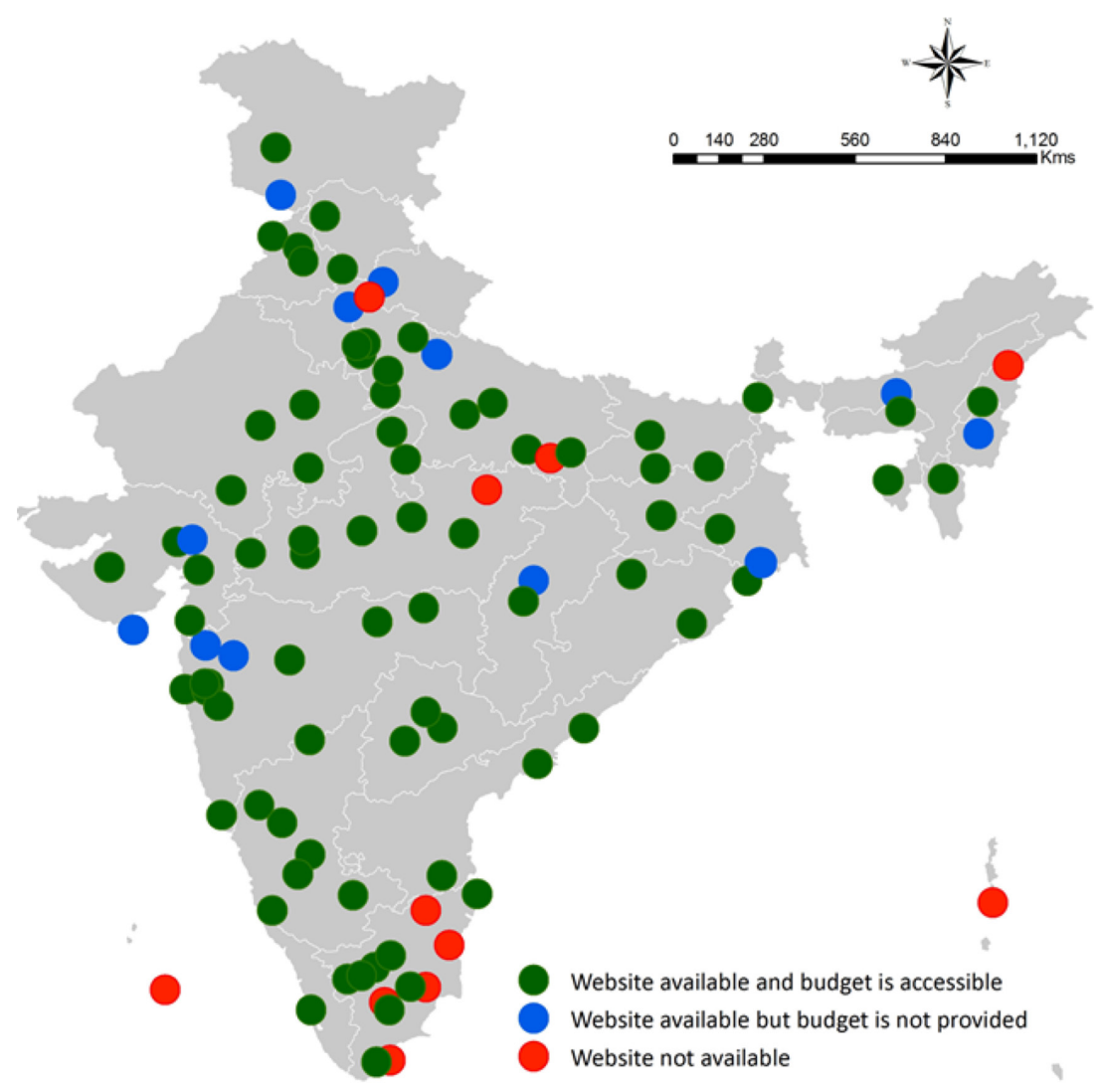

Figure 4: Availability of municipal website and E-budget in designated smart cities. 
continuous basis. Our analysis of the information obtained from service level benchmark data published by Government of India and various cities show that till date, more than one-third of the designated smart cities have still not started collecting and reporting data on service levels. This lack of aggregated data at city level is primarily attributed to fractured institutional mandates and unaccountable parastatal organisations that provide the bulk of physical infrastructure in Indian cities. Furthermore, our analysis shows that only 9 out of 100 identified smart cities in India has set up single window civic service centres at the municipal corporation. The rest have failed to develop this elementary system that enables people to approach a single point of contact to facilitate disposal of all type of applications and grievances concerning civic services. The failure of large majority cities to set up the single window civic service centres highlights that Indian cities lack coordination mechanism across service delivery institutions. Overall, the municipal corporations are yet to emerge as fully empowered agencies that can deal with the demand of such simplified service delivery mechanisms.

The above discussions establish the fact that Indian cities possess a traditional mode of government that needs to do the fundamentals right before it can imagine transforming itself into smart governance. Presently, none of the Indian cities is using sensor or IoT to capture real-time data that feed into decision making as explained in the second conceptualisation of smart governance in section 2. Government silos and splintered data management system are restricting them to develop open data platforms. Further interconnection of government departments through ICT (Type III conceptualisation of smart governance) seems unrealistic at the moment due to a strong presence of the parastatal organisations and urban local bodies not in a position to take the leading role. Two different options emerge from here for Indian cities to adopt for becoming smart cities. The first one is aggressive place marketing and branding rather than changing the structure or process of governance. Such a strategy might be an easy-to-go option, and in-fact many cities might have already started following it [5], but in the long run, it shows no promise of uplifting the infrastructure standards or quality of life and economy. The second strategy which seems more appropriate considering the existing state of governance is strengthening of civic administration [6] and integration of digital technology for reforms in service delivery to citizens. In the following section, let us explore which approach Indian cities are adopting: the soft to go approach with aggressive place marketing or a more practical strategy of establishing long-term institutional transformation procedures in the purview of the Smart Cities Mission.

\section{EMERGING FORM OF GOVERNANCE IN INDIA'S SMART CITIES}

Citing lack of resources and capacity of urban local bodies to raise revenues and manage large-scale development projects, Government of India, in its Smart Cities Mission Statement and Guidelines [35] proposed formulation of Special Purpose Vehicle's (SPV) as a nodal implementing agency for smart city projects. These SPV's are being set up as an independent and autonomous company with 50:50 shareholdings between the state government and municipal corporation. The vehicles are headed by a CEO, supported by a directorial board with representation from central government, state government and local level public utility providing agencies. The CEO and the smart city SPV is entrusted with planning, appraisal, approval, releasing of funds, implementation, management, operation, monitoring and evaluation of smart city development projects.

The general idea behind assigning SPV's instead of Municipal Corporation for project planning and execution is to exhibit a high-performance urban system and bring agility in 
strategic decision making [36]. The SPV's are being set up as a corporate body (functioning under the Companies Act, 2013) that can take up processes and execute mechanisms which the municipal governments may not be empowered to perform as per prevailing laws and regulations. The SPV's will have the power to perform activities such as raising large debts, entering into joint venture arrangements with private organisations, selling of assets etc., functions for which urban local bodies require special approval from the state government. The SPVs are also appearing to be well positioned to engage citizens through ICT mediums, which otherwise could not be performed due to the multiplicity of institutions and lack of modernisation in government organisations.

Apart from setting up SPV's, aspiring Indian smart cities are forming Smart City Advisory Forum at the city level aiming to drive collaboration among various stakeholders. The forum consists of CEO of SPV, Collector of the concerned district, members of the Legislative Assembly and Parliament, City Mayor, Municipal Commissioner, selected technical experts from academia and industry, members of the registered residents association, the leadership of slum level federation and members of recognised non-government organisations. The key role of this forum is to review suggestions provided by citizens, prioritise projects and do a periodic review of the project outcomes. This nature of consultative structure was never seen in existence in India's urban landscape and is believed to be the beginning of collaborative governance in Indian cities.

To provide more in-depth insights about the governance structure of the vehicle, this research has analysed organisational framework of Bhubaneswar Smart City (www.smartcitybhubaneswar.gov.in), which is one of the early establishers of a full-fledged SPV. Located in the eastern Indian state of Odisha, the city of Bhubaneswar has conceived SPV as a master developer, more in the style of private townships. It is looking to enter into arrangements with builders, technology vendors and financiers to redevelop its town centre district and develop an integrated transit hub adjoining its central railway station. As shown in Fig. 5, the Bhubaneswar Smart City SPV is headed by a full-time CEO who is a bureaucrat in the rank of Indian Administrative Services. The CEO is supported by General Manager Engineering and Technology, General Manager Operations and Chief Financial Officer. An independent entity named "Bhubaneswar Urban Knowledge Centre (BUKC)" is being set up to assist the

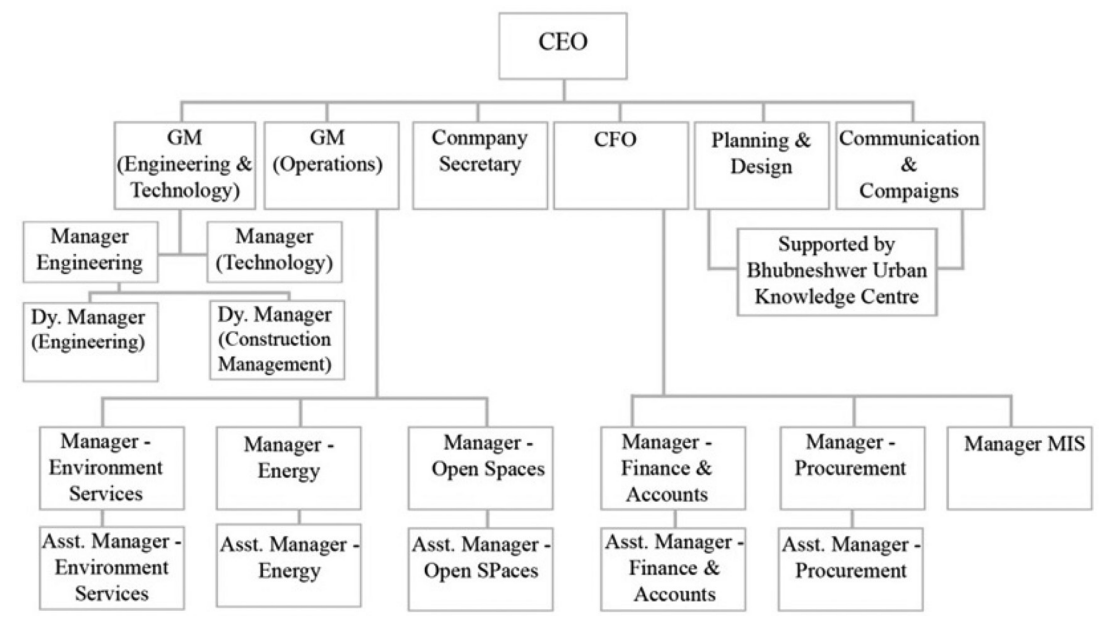

Figure 5: Organisational structure of Bhubaneswar Smart City SPV. 
CEO in delivering planning and design functions as well as citizen outreach. BUKC will be based within Bhubaneswar Urban Development Authority (BDA) but staffed by a project management consultant (PMC). The execution of infrastructure projects is also planned to be undertaken by PMC's and parastatal organisations. It is quite clear from the organogram that the SPV has little provision for in-house technical staff, indicating that their role will be to monitor and coordinate the developments rather than designing or physical implementation.

It is apparent from the above discussions that smart cities mission has infused a new model of urban governance in Indian cities, having the ability to speed up the process of infrastructure development- which do not involve municipal corporations directly. A sincere attempt can also be seen aiming the development of collaborative systems to engage urban stakeholders and citizens in the decision making process. Indian cities are certainly making efforts to transform the way they govern to emerge as future smart cities; moving beyond marketing strategy or digital technology-driven models of smart urban governance. However, this SPV driven urban development apparently bypasses the existing governance mechanisms that include dully elected municipal corporations and state level utility providing agencies.

Specific groups [5] observes this as an informed design to drive a broader agenda of sidestepping the democratic process of local self-government by replacing them with more capitalistic business oriented entities. This argument is reinforced by state and central advisory issued to municipal government's asking them to delegate rights and obligations of infrastructure development functions to SPV's. Whereas for last two decades a lot has been invested for uplifting the capacity of municipal corporations in the true spirit of the 74th CAA, this sudden shift in government policy is set to undermine the entire process of empowerment of the ULB's. Furthermore, rather than simplifying and integrating the governance systems, the SPV has only added a new layer, as the state level agencies continue to play a key role in overall city infrastructure development. Therefore smart cities governance in India has fallen short of addressing the systematic capacity building needs and strengthening of local municipal bodies and is unpathetic towards solving the existing institutional overlaps and complex policy mandates. At the moment it is challenging to comprehend how such a newly formed corporate entity will coordinate with the current fractured governance system, and develop the managerial capability to deliver expected urban transformation within five years of its life cycle.

\section{CONCLUSIONS AND WAY FORWARD}

One of the key features of India's urban management practice is that without any concrete urban development policy in place the country follows a model of instant urbanism [36] enabled by fast policy, targeted for short-term goals. Because of failure to learn from past initiatives such as JnNURM, policymaking is often 'reinventing the wheel'. The SPV model of urban governance introduced under the Smart Cities Mission highlights the nature of short-terminism reflecting the false assumption that deep-seated structural governance issues can be addressed by temporary solutions, as opposed to consistent, long-term processes towards institutional transformation. This study finds that emerging smart cities governance in India encourages institutional compartmentalism due to poor convergence and integration mechanism among interventions, which fails to realise the added value offered by coordination of resources and from the joint efforts of agencies.

Cities in India are snowballing, adding new complexities to urban issues. Championing such problems in modern societies require collaboration and integrated thinking. India needs 
to incorporate learnings from the past and develop its framework of smart cities governance, customised to local institutional context and that prioritises the democratic aspirations of its citizens. Simply, setting up of semi privatised corporate body in the line of Songdo, South Korea or a mere conceptualisation of Smart City Advisory Forum, typically borrowed from structures such as Smart London Board, may not solve the inherent constraints in urban governance. What Indian cities need in the present context is not smartness but functionality; not technological efficiency so much as equity.

It's still early days of smart cities development in India. We will continue to monitor India's smart city development as it unfolds. But, one thing to be sure, to shape sustainable smart cities, India need to encourage the development of municipal government's as empowered and accountable entities; not living in the mercy of its powerful states or with huge liabilities to corporate bodies such as SPV. They need to take control of their destinies, become deliberate about their economic growth, and devolve powers to the places and people who are closest to the ground. By introducing a new model of project execution, Government of India might have acknowledged that Indian municipal governments are not in a position to deal with large-scale digital urban renewal initiatives. But, beyond the smart enclaves under the purview of SPV's, there is still a city to govern; a city that also dreams to become smart.

\section{REFERENCES}

[1] World Economic Forum. Reforms to Accelerate the Development of India's Smart Cities: Shaping the Future of Urban Development \& Services, Geneva: WEF; 2016.

[2] Ahluwalia, I.J. \& Mohanty, P.K., Planning and market for urban development in India. In Urbanisation in India, eds I.J. Ahluwalia, R. Kanbur, P.K. Mohanty, New Delhi: Sage, pp. 56-81, 2014.

[3] Government of India. Strategic Plan of Ministry of Urna Development for 2011-16. New Delhi: Government of india, Ministry of Urban Development, 2015.

[4] Bholey, M., India's urban challenges and smart cities: a contemporary study. International Journal of Business Policy \& Governance, 3(3), pp. 2394-3351.

[5] Chattaraj, S., International Growth Centre - Ideas for growth, available at http:// www.theigc.org/blog/are-smart-cities-enough-for-india/ (accessed 12 January 2017)

[6] Ravi, S. \& Bhatia, A., The Wire, available at https://thewire.in/56022/smart-cities-tosucceed-need-to-strengthen-local-governance/ (accessed 1 February 2017)

[7] Brookings Institution. Building Smart Cities in India, Washington, DC; 2016.

[8] Rakodi, C., Politics and performance: the implications of emerging governance arrangements for urban management approaches and information systems. Habitat International, 27(4), pp. 523-547, 2003. https://doi.org/10.1016/S0197-3975(03)00004-3

[9] Stoker, G., Public-private partnerships and urban governance. In Partnerships in urban governance: European and American experience ed. J. Pierre, Basingstoke: Macmillan, pp. 34-51, 1998. https://doi.org/10.1007/978-1-349-14408-2_3

[10] United Nations Centre for Human Settlements. Cities in a globalizing world: Global report on human settlements. London: UN; 2001.

[11] Kearns, A. \& Paddison, R., New Challenges for Urban Governance. Urban Studies, 37(5-6), pp. 845-850, 2000.

https://doi.org/10.1080/00420980050011118 
[12] Nam, T. \& Pardo, T.A., Smart city as urban innovation: focusing on management, policy and context. In Proceedings of the 5th International Conference on Theory and Practice of Electronic Governance, New York. pp. 185-194, 2011. https://doi.org/10.1145/2072069.2072100

[13] Hollands, R.G., Will the real smart city please stand up? City, 12(3), pp. 303-320, 2008. https://doi.org/10.1080/13604810802479126

[14] European Parliament. Mapping smart city in the EU. Brussels: European Parliament, 2014.

[15] Meijer, A. \& Bolivar, M.P., Governing the smart city: a review of the literature on smart urban governance. International Review of Administrative Sciences, 82(2), pp. 392 408, 2015. https://doi.org/10.1177/0020852314564308

[16] Harvey, D., Spaces of Hope Harvey D, editor, California: University of California Press, 2000.

[17] Nam, T., Modeling municipal service integration: A comparative case study of New York and Philadelphia. Dissertation, New York: State University of New York at Albany, 2012.

[18] Batty, M., Axhausen, K.W., Giannotti, F., Pozdnoukhov, A., Bazzani, A., Wachowicz, M., Portugali, Y.O., Smart cities of the future. European Physical Journal, 214, pp. 481-518, 2012.

https://doi.org/10.1140/epjst/e2012-01703-3

[19] González, S., Bilbao and barcelona 'in motion'. how urban regeneration 'models' travel and mutate in the global flows of policy tourism. Urban Studies, 48(7), pp. 1397-1418, 2011. https://doi.org/10.1177/0042098010374510

[20] Schuurman, D., Baccarne, B., De Marez, L. \& Mechant, P., Smart ideas for smart citie. Journal of Theoretical and Applied Electronic Commerce Research, 7(3), pp. 49-62, 2012.

[21] UNESCAP, United Nations, ESCAP, available at: http://www.unescap.org/resources/ what-good-governance (accessed 16 January 2017)

[22] Deakin, M., Smart Cities: Governing, modelling and analysing the transition Deakin M, editor, New York: Routledge, 2014.

[23] Gil-Garcia, R., Enacting Electronic Government Success: An Integrative Study of Government-wide Websites, Organizational Capabilities, and Institutions ed R. Gil-Garcia, New York: Springer, 2012.

[24] Torfing, J.B., Peters, G., Pierre, J. \& Sorensen, E., Interactive Governance: Advancing the Paradigm eds J.B. Torfing, G. Peters, J. Pierre, E. Sorensen, Oxford: Oxford University Press, 2012.

[25] Kourtit, K., Nijkamp, P. \& Arribas, D., Smart cities in perspective - a comparative European study by means of self-organizing maps. Innovation: The European Journal of Social Science Research, 25(2), pp. 229-246, 2012. https://doi.org/10.1080/13511610.2012.660330

[26] Kundu, D., Urban development programmes in india: a critique of JnNURM. Social Change, 44(4), pp. 615-632, 2014. https://doi.org/10.1177/0049085714548546

[27] Sivaramakrishnan, K.C., Re-Visioning Indian Cities: The Urban Renewal Mission ed. K.C. Sivaramakrishnan, New Delhi: Sage India, 2011. https://doi.org/10.4135/9788132107859 
[28] High Powered Expert Committee. Report on urban infrastructure and services. New Delhi: Government of India, 2011.

[29] Vaidya, C., Urban Issues, Reforms and Way Forward in india. New Delhi: Ministry of Finance, Government of India, Department of Economic Affairs, 2009.

[30] Okot-Uma RWO, London CS. Electronic governance: re-inventing good governance. London: Commonwealth Secretariat, 2000.

[31] van den Haak, M.J., de Jong, M.D., Schellens, P.J., Evaluating municipal websites: A methodological comparison of three think-aloud variants. Government Information Quarterly, 261(1), pp. 193-202, 2009. https://doi.org/10.1016/j.giq.2007.11.003

[32] Aguilera, R.V. \& Cuervo-Cazurra, A., Codes of good governance worldwide: what is the trigger? Organization Studies, 25(3), pp. 415-443, 2004. https://doi.org/10.1177/0170840604040669

[33] Giffinger, R., Fertner, C., Kramar, H., Kalasek, R., Pichler-Milanovic', N. \& Meijers, E., Smart Cities: Ranking of European Medium-Sized Cities. Vienna: Vienna UT, 2007.

[34] Development MoU. Mission statement and guidelines. New Delhi: Government of India, Ministry of Urban Development, 2015.

[35] Sandhir, S., How will a SPV in a smart city work? available at http://www.hindustantimes.com/real-estate/how-will-a-spv-in-a-smart-city-work/story-2zSGIwMztItpzPZA9TuXeM.html (accessed 10 February 2017)

[36] Roy, A., Why India cannot plan its cities: informality, insurgence and the idiom of urbanization. Planning Theory, 8(1), pp. 76-87, 2009.

https://doi.org/10.1177/1473095208099299 